\title{
PENGEMBANGAN MODEL PENILAIAN AUTENTIK DALAM PEMBELAJARAN TEMATIK BERBASIS HIGHER ORDER THINKING SKILL (HOTS) PADA MADRASAH IBTIDAIYAH DI KECAMATAN GEBOG KABUPATEN KUDUS
}

\author{
Mahfud Nahrowi \\ Mahasiswa Pascasarjana IAIN salatiga, Salatiga, Indonesia \\ Owimahfud.kudus@gmail.com
}

\begin{abstract}
The study aims to develop authentic assessment model in HOTSbased thematic learning for the fifth grade teachers of Madrasah Ibtidaiyah in Subdistrict of Gebog in Kudus Regency. This research method used Research and Development $(R \mathcal{E} D)$ design from Borg and Gall. The model development procedure used five steps of ADDIE, namely analyze, design, development, implementation, and evaluation. The sources of data were the documentation of teacher assessment performance, questionnaire, observation, interview, and model trial. The research subjects were the teachers and the principal. The techniques and instruments for collecting data used questionnaire, interview, observation, documentation and test. Validity test of the data used triangulation. Data analysis techniques used quantitative and qualitative. Result of the research shows the development of curriculum 2013 authentic assessment model in HOTS-based thematic learning for the fifth grade teachers of Madrasah Ibtidaiyah in Subdistrict of Gebog is very important and needed starting from performance system; planning, implementation, evaluation, reporting and following-up. It is also component system; teacher and infrastructure. The development product is a guidebook in HOTS-based thematic learning. The proper test result of a guidebook
\end{abstract}


from experts and practitioners obtained value of 83.33 in the very feasible category. The results of limited trials and expanded trials in using product described by improving the quality of teachers' ability in doing authentic assessment was 30,29\% of limited trials 54,29\% increased to $84.57 \%$ so that the product is effective and appropriate used as guidance by the fifth grade teachers of Madrasah Ibtidaiyah in Gebog Subdistrict.

Keywords: Authentic Assessment, Tematic Learning, Higher Order Thinking Skill (HOTS)

\section{A. Pendahuluan}

Penilaian di Madrasah Ibtidaiyah (MI) merupakan suatu keniscayaan. Penilaian sangat penting, karena berfungsi sebagai sumber informasi, alat evaluasi, serta berperan untuk menentukan arah, kualitas, dan ketercapaian tujuan standar nasional pendidikan. Oleh karena itu, kurikulum 2013 menekankan penyempurnaan standar isi dan standar penilaian. Standar isi dirancang agar siswa mampu berpikir kritis dan analitis sesuai dengan standar internasional. Standar penilaian dilakukan dengan mengadaptasi model-model penilaian standar internasional secara bertahap dengan menekankan pada penilaian autentik dan kemampuan berpikir tingkat tinggi (Higher Order Thinking Skills/HOTS).

Penilaian autentik (authentic assessment) merupakan penilaian yang dilakukan secara komprehensif untuk menilai mulai dari masukan (input), proses, dan keluaran (ouput) pembelajaran (Gultom, 2014: 3). Penilaian autentik memiliki relevansi kuat terhadap pendekatan scientific dalam pembelajaran sesuai dengan tuntutan Kurikulum 2013, sehingga cocok diterapkan di MI/SD. Penilaian autentik mampu menggambarkan peningkatan hasil belajar melalui mengobservasi, menalar, mencoba, membangun jejaring untuk meningkatkan kompetensi siswa, sesuai dengan tuntutan kompetensi yang ada di standar kompetensi (SK), kompetensi inti (KI), dan kompetensi dasar (KD) (Kunandar, 2015: 35). Penilaian autentik bertujuan melacak kemajuan siswa, mengecek ketercapaian kompetensi, dan umpan balik. Prinsip penilaian autentik yaitu: untuk 
penelusuran (keeping track), pengecekan (checking-up), dan pencarian (finding out), dan penyimpulan (summin-up). (Todorof, 2009: 325).

Penilaian autentik dijadikan sebagai model penilaian utama dalam kurikulum 2013 di tingkat SD/MI. Penilaian autentik dijadikan sebagai alasan dalam penilaian utama pada kurikulum 2013 karena (1) penilaian autentik dilakukan secara komprehensif meliputi ranah sikap, pengetahuan, dan keterampilan; (2) memiliki relevansi kuat terhadap pendekatan ilmiah (scientific approach); (3) mendasarkan diri pada prinsip-prinsip objektif, terpadu, transparan, akuntabel, dan edukatif (Gultom, 2014: 3). Penilaian autentik dapat dijadikan sebagai bukti nyata atas apa yang telah dikuasai siswa (Mueller, 2005: 1418). Penilaian autentik bertolak dari pengalaman pribadi, langsung nyata pada siswa (Masrukin, 2014: 724).

Penilaian autentik kurikulum 2013 memiliki keunggulan baik secara teoretis maupun praksis. Keunggulan teoretisnya yaitu memerhatikan keseimbangan antara penilaian kompetensi sikap, pengetahuan, dan keterampilan (Basuki, 2014: 13). Penilaian autentik memungkinkan guru melakukan penilaian secara komprehensif mencakup aspek afektif, kognitif, dan psikomotorik (Masrukin, 2014: 724). Keunggulan praksisnya yaitu (1) mencerminkan kondisi nyata pembelajaran di kelas; (2) menggunakan jenis alat penilaian seperti rubrik penskoran, portofolio, penilaian diri, interview, proyek (Enggarwati, 2015: 3). Penilaian autentik selalu memberi kesempatan kepada siswa menunjukkan pengetahuan dan keterampilannya (Moon, 2016: 89).

Secara faktual penilaian autentik menekankan pada keterpaduan antara penilaian sikap, pengetahuan dan keterampilan. Komponen penilaian sikap meliputi Sikap Spiritual (KI-1) di dalamnya mencakup (1) Ketaatan beribadah, (2) Berperilaku syukur, (3) Berdoa sebelum dan sesudah, dan (4) Toleransi Berbadah, sedangkan Sikap Sosial (KI-2) terdiri atas (1) Jujur, (2) Disiplin, (3) Tanggung jawab, (4) Santun, (5) Peduli dan (6) Percaya Diri. Teknis penilaian sikap dilakukan melalui lembar observasi guru, penilaian diri peserta didik dan penilaian antar teman. Komponen penilaian pengetahuan (KI-3) terdiri atas tes tertulis, tes lisan, penugasan 
yang dituangkan dalam penilaian harian, penilaian tengah dan akhir semester. Komponen Penilaian Keterampilan (KI-4) dilaksanakan dengan menggunakan penilaian kinerja, penilaian proyek, penilaian produk dan penilaian portofolio.(Dok. Buku Daftar Penilaian hasil Belajar MI Kementerian Agama kabupaten Kudus 2019).

Fakta yang peneliti temukan, sebagian guru masih enggan melaksanakan penilaian autentik yang ideal dengan instrumentinstrumen yang dituangkan dalam rubric-rubrik penilaian. Hal ini didasarkan pada hasil monitoring, bahwa guru dalam melaksanakan penilaian autentik masih bersifat administratif. Guru SD/MI hanya menuangkan nilai ke dalam buku daftar nilai hasil belajar hanya berdasarkan pada observasi guru semata, dan itupun tanpa ditunjang dengan penskoran yang obyektif. Bahkan terkesan hanya "ngaji" (ngarang biji-jawa). Faktor utamanya karena guru masih kesulitan dalam mengolah data dalam mendeskripsikan capaian sikap, pengetahuan, dan keterampilan yang akan dituliskan dalam raport (Hanif, 2017: 99), menentukan kriteria penilaian, membuat instrumen penilaian, membuat indikator penilaian serta mengimplementasikan penilaian dalam proses belajar mengajar sampai menyampaikan laporan hasil belajar dalam bentuk nilai raport (Rahmanto, 2013: 10).

Hasil wawancara pendahuluan dengan Pengawas, Kepala Madrasah dan guru MI di Kecamatan Gebog dinyatakan bahwa sebagian besar guru dalam melakukan penilaian autentik masih bersifat administratif. Artinya dalam melaksanakan penilaian autentik guru masih bersifat formalitas untuk memenuhi kelengkapan dokumen administrasi saja ketika disupervisi (Ni'am, 2019). Guru MI baru sekitar 60\% yang mampu merancang, melaksanakan, mengolah, melaporkan, dan memanfaatkan hasil penilaian dengan baik sedangkan masih 40\% guru masih mengalami kesulitan. (Musyaddad, 2019). Guru MI di Kecamatan Gebog sebagian besar enggan menggunakan penilaian autentik, karena masih mengalami kesulitan dalam merumuskan indikator, menyusun butir-butir soal untuk pengetahuan faktual, konseptual, prosedural, dan metakognitif yang dikombinasikan dengan keterampilan berpikir tingkat rendah hingga tinggi, membuat rubrik penskoran (Umiyati, 2019). 
Kondisi ini dialami oleh sebagian besar guru MI di Kecamatan Gebog dalam melaksanakan penilaian autentik yang sesuai dengan kurikulum 2013. Berbagai upaya telah dilakukan Kementerian Agama Kabupaten Kudus, Kelompok Kerja madrasah (KKM) dan sekolah melalui pelatihan, workshop, bintek dan In House Trainning (IHT), dan supervisi. Namun upaya tersebut masih belum memperoleh hasil yang memuaskan. Guru dalam praktik penilainnya masih menggunakan "madzhab" kurikulum KTSP. Berawal dari fenomena tersebut peneliti akan mencoba menggugah semangat guru di Kecamatan Gebog dengan pendampingan dan pelatihan menggunakan buku panduan model penilaian autentik berbasis soal-soal HOTS yang menjadi tren penilaian abad ke-21.

Higher Order Thinking Skills (HOTS) merupakan kemampuan untuk menghubungkan, memanipulasi, dan mengubah pengetahuan serta pengalaman yang sudah dimiliki secara kritis dan kreatif dalam menentukan keputusan untuk menyelesaikan masalah pada situasi baru (Supriano, 2018: 1). Higher Order Thinking Skills merupakan kemampuan berpikir kritis, logis, reflektif, metakognitif, dan kreatif (Supriano, 2018: 1).

Pada penelitian ini penulis lebih menitikberatkan pada penilaian autentik bagi guru kelas V MI di Kecamatan Gebog berbasis HOTS, dengan alasan karena orientasi pengembangan pembelajaran terletak pada keterampilan berpikir tingkat tinggi. Higher Order Thinking Skills bertujuan menumbuhkan berpikir kritis, logis, reflektif, metakognitif, dan kreatif (King, 2011: 162). meningkatkan kemampuan berpikir pada level yang lebih tinggi (Barnet, 2016: 201). Higher Order Thinking Skills memiliki keunggulan karena: (1) para guru membuat kebaruan-kebaruan dalam proses belajar serta melatih daya nalar guru dan siswa dalam berpikir kritis; yang meliputi level: C1 (knowledge) C2 (comprehension), C3: (application), C4: (analysis), C5 (synthesis), dan C6 (evaluation) (Dini, 2018: 170). (2) HOTS terintegrasi dengan penguatan pendidikan karakter (Supriano, 2018: 1). Siswa kelas $\mathrm{V}$ dipandang sudah mampu untuk diajak berpikir tingkat tinggi menggunakan HOTS. 
Berdasarkan latar belakang tersebut di atas, maka peneliti tertarik untuk mengangkat "Model Penilaian Autentik dengan Pendekatan Higher Order Thinking Skill (HOTS) Berbasis Kebutuhan Guru Madrasah Ibtidaiyah di Kecamatan Gebog Kabupaten Kudus" sebagai judul dalam jurnal ini.

Penelitian ini, hasilnya diharapkan bermanfaat baik secara teoritis maupun praksis bagi Kementerian Agama dan guru Madrasah Ibtidaiyah di Kabupaten Kudus.

\section{B. Pembahasan}

\section{Metode Penelitian}

Desain penelitian ini menggunakan metode penelitian pengembangan atau Research and Development (R \& D). Prosedur pengembangan model dilakukan dengan menggunakan Model ADDIE yang dikembangkan oleh Dick and Carry (1996) yakni: (1) analisis (analyze), (2) perancangan (design), (3) pengembangan (development), (4) implementasi (implementation), dan (5) evaluasi (evaluation) (Tengeh, 2013: 15). Sumber data yang digunakan dalam penelitian ini bersumber dari guru, Kepala Madrasah dan Pengawas. Sumber data berupa data dokumentasi kinerja guru dalam penilaian autentik, angket, observasi, wawancara, ujicoba model penilaian autentik berbasis HOTS. Subjek penelitian adalah guru dan Kepala Madrasah. Teknik dan instrumen pengumpulan data yang digunakan dalam penelitian ini meliputi kuesioner, angket, wawancara, observasi, dokumentasi dan tes. Uji keabsahan data menggunakan triangulasi dan perpanjangan keikutsertaan. Uji validitas data menggunakan validitas konstruk dan validitas item; dan uji reliabilitas reliabelitas menggunakan uji confirmability. Teknik analisis data menggunakan kuantitatif dan kualitatatif. Teknik analisis kuantitatif deskripsi digunakan untuk menganalisis data yang berasal dari tahap studi pendahuluan, tahap pengembangan, validasi dan uji coba terbatas dan diperluas, serta hasil uji validasi kelayakan dari pakar dan praktisi. Teknik analisis kualitatif deskriptif, peneliti menggunakan display data, reduksi data, verifikasi data dan penarikan kesimpulan. 


\section{Hasil Penelitian}

\section{a. Kondisi Faktual Penilaian Autentik kurikulum 2013}

Hasil penelitian pendahuluan tentang kondisi faktual penilaian autentik kurikulum 2013 di MI Kecamatan Gebog yang selama ini dilaksanakan oleh guru, menunjukkan bahwa secara umum hasilnya dipersepsi responden dalam kategori kurang baik. Hasil kinerja sistem dan komponen sistem penilaian autentik kurikulum 2013 guru yang selama ini dilaksanakan disajikan pada tabel 1 .

Tabel 1. Pendapat Responden tentang Kinerja Sistem dan Komponen Sistem Manajemen Penilaian Autentik Kurikulum 2013 yang selama ini dilaksanakan Guru MI di Kecamatan Gebog Kabupaten Kudus

\begin{tabular}{llccccc}
\hline No & Substansi Item & Skor & Rerata & Rentang & $\begin{array}{c}\text { Rerata } \\
\text { Konversi } \\
(\%)\end{array}$ & Kategori \\
\hline A. & Kinerja Sistem & 2717 & 136,25 & $110-158$ & 53,97 & KB \\
\hline 1. & Perencanaan & 675 & 33,75 & $25-36$ & 58,06 & KB \\
\hline 2. & Pelaksanaan & 880 & 44,40 & $35-52$ & 49,88 & KB \\
\hline 3. & Evaluasi & 451 & 22,55 & $19-26$ & 51,08 & KB \\
\hline 4. & Pelaporan & 367 & 18,35 & $12-18$ & 57,34 & KB \\
\hline 5. & Tindak lanjut & 344 & 17,20 & $12-18$ & 53,50 & KB \\
\hline B. & $\begin{array}{l}\text { Komponen } \\
\text { Sistem }\end{array}$ & 830 & 41,50 & $34-50$ & 49,95 & KB \\
\hline 6. & Guru & 636 & 31,80 & $26-38$ & 49,90 & KB \\
\hline 7. & $\begin{array}{l}\text { Sarana dan } \\
\text { prasarana }\end{array}$ & 194 & 9,70 & $6-10$ & 50,00 & KB \\
\hline & $\quad$ Jumlah & 3547 & 177,75 & $139-200$ & 54,86 & KB \\
\hline
\end{tabular}

Tabel 1. dideskripsikan ringkasan hasil kinerja sistem penilaian autentik kurikulum 2013 yang selama ini dilaksanakan dalam kategori kurang baik dengan total rerata skor 136,25 berada di rentang 110-158 dengan konversi nilai 53,97. Kategori kurang baik tersebut terdistribusi untuk indikator perencanaan diperoleh rerata skor 33,75 berada di rentang 25-36 konversi nilai 58,06. Indikator pelaksanaan diperoleh rerata skor 44,40 berada di rentang 35-52 konversi nilai 49,88. Indikator evaluasi diperoleh rerata skor 22,55 berada di rentang 19-26 konversi nilai 51,06. Indikator pelaporan 
diperoleh rerata skor 18,35 berada di rentang 12-18 konversi nilai 57,34 . Indikator tindak lanjut diperoleh rerata skor 17,20 berada di rentang 12-18 konversi nilai 53,50.

Hasil penilaian komponen sistem penilaian autentik kurikulum 2013 disajikan yang selama ini dalam kategori kurang baik dengan total rerata skor 41,50 berada di rentang 34-50 konversi nilai 49,95. Kategori kurang baik tersebut terdistribusi untuk indikator dari komponen guru dengan rerata skor 31,80 berada di rentang 26-38 konversi nilai 49,90. Indikator sarana dan prasarana rerata skor 9,70 berada di rentang 6-10 konversi nilai 50,00.

Berdasarkan hasil temuan model faktual diperoleh gambaran tentang manajemen kinerja sistem dan komponen sistem penilaian autentik kurikulum 2013 guru MI di Kecamatan Gebog yang selama ini dilaksanakan. Manajemen kinerja sistem penilaian autentik kegiatannya mencakup aspek perencanaan, pelaksanaan, evaluasi, pelaporan dan tindak lanjut. Perencanaan kegiatannya meliputi: perumusan tujuan penilaian, penentuan bentuk, teknik, kisi-kisi dan waktu. Pelaksanaan penilaian, kegiatannya meliputi: mempersiapkan perangkat, menentukan KKM, melaksanakan penilaian, pengoreksian, analisis dan pengolahan nilai. Evaluasi kegiatannya meliputi: evaluasi perencanaan dan pelaksanaan penilaian. Pelaporan kegiatannya meliputi: pelaporan kepada kepala sekolah dan orang tua dan instansi yang terkait. Tindak lanjut, kegiatannya meliputi: remedial dan pengayaan. Komponen sistem penilaian autentik kurikulum 2013, meliputi aspek: guru dan sarana prasarana berupa buku panduan dan media serta peralatan TIK.

\section{b. Desain Model Penilaian Autentik Kurikulum 2013 dengan Pendekatan HOTS}

Pengembangan model penilaian autentik kurikulum 2013 dengan pendekatan HOTS berbasis kebutuhan guru MI di Kecamatan Gebog Kudus didapatkan dari hasil analisis kebutuhan yang meliputi: analisis kinerja sistem, komponen sistem dan pendekatan HOTS. Ringkasan hasil analisis kebutuhan disajikan pada tabel 2. 
Tabel 2.Hasil Keseluruhan Sebaran Jawaban Responden tentang Penilaian Autentik Kurikulum 2013 dengan Pendekatan HOTS

\begin{tabular}{|c|c|c|c|c|c|c|}
\hline No & Sub item & Skor & Rerata & Rentang & $\begin{array}{c}\text { Rerata } \\
\text { Konversi } \\
(\%)\end{array}$ & Kategori \\
\hline \multirow{6}{*}{ A. } & Kinerja Sistem & 4636 & 231,80 & $208-256$ & 89,61 & SP \\
\hline & 1. Perencanaan & 1086 & 54,30 & 49-60 & 91,06 & SP \\
\hline & 2. Pelaksanaan & 1633 & 81,65 & $71-88$ & 92,36 & SP \\
\hline & 3.Evaluasi & 813 & 40,65 & $36-44$ & 92,04 & SP \\
\hline & 4.Pelaporan & 571 & 28,55 & $26-32$ & 89,22 & $\mathrm{SP}$ \\
\hline & 5.Tindak Lanjut & 533 & 26,65 & $26-32$ & 83,38 & SP \\
\hline \multirow{3}{*}{ B. } & $\begin{array}{l}\text { Komponen } \\
\text { Sistem }\end{array}$ & 1455 & 72,75 & $68-84$ & 86,44 & SP \\
\hline & 1. Guru & 1115 & 55,75 & $52-64$ & 87,56 & SP \\
\hline & $\begin{array}{l}\text { 2. Sarana dan } \\
\text { Prasarana }\end{array}$ & 340 & 17,00 & $16-20$ & 85,31 & SP \\
\hline \multirow{4}{*}{ C. } & HOTS & 705 & 35,25 & $33-40$ & 87,57 & SP \\
\hline & 1. LOTS & 205 & 10,25 & $10-12$ & 85,42 & SP \\
\hline & 2. MOST & 140 & 7,00 & $7-8$ & 87,30 & SP \\
\hline & 3. HOTS & 360 & 18,00 & $16-20$ & 90,00 & $\mathrm{SP}$ \\
\hline \multicolumn{2}{|r|}{$\begin{array}{c}\text { Jumlah Seluruh } \\
\text { Indikator }\end{array}$} & 6796 & 339,8 & $308-380$ & 263,62 & SP \\
\hline \multicolumn{2}{|r|}{$\begin{array}{l}\text { Rerata Seluruh } \\
\text { Indikator }\end{array}$} & 2265,33 & 113,27 & $103-127$ & 87,87 & SP \\
\hline
\end{tabular}

Pada tabel 2 didiskripsikan hasil analisis kebutuhan penilaian autentik kurikulum 2013 berbasis HOTS dalam kategori sangat penting rerata skor 339,8 berada di rentang 308-380 konversi nilai $87,87 \%$. Kategori sangat penting tersebut terdistribusi untuk analisis kebutuhan kinerja sistem dengan rerata skor 231,80 berada di rentang 208-256 konversi nilai 89,61\%; komponen sistem rerata skor 72,75 berada di rentang 68-84 dengan konversi nilai $86,44 \%$; HOTS diperoleh rerata skor 35,25 berada di rentang 33-40 dengan konversi nilai $87,57 \%$.

Nilai hasil analisis kebutuhan kinerja sistem tertinggi yaitu pelaksanaan dengan perolehan nilai 92,36. Artinya 92,36\% responden menyatakan bahwa pelaksanaan penilaian autentik sangat penting, hanya $7,64 \%$ kurang penting. Indikator pelaksanaan yang dianggap penting meliputi: persiapan perangkat penilaian, penetapan 
KKM, pelaksanaan penilaian, pengoreksian, analisis penilaian dan pengolahan nilai. Pelaksanaan merupakan inti dari kegiatan penilaian dan menjadi tolak ukur keberhasilan dalam penilaian. Pelaksanaan penilaian autentik kurikulum 2013 aspek yang dinilai meliputi ranah pengetahuan, keterampilan dan sikap. Nilai hasil analisis kinerja sistem terendah adalah tindak lanjut dengan perolehan nilai 83,38 . Artinya $83,38 \%$ responden menyatakan bahwa tindak lanjut penilaian sangat penting, hanya $16,62 \%$ kurang penting dan tidak penting. Indikator yang dianggap penting yaitu remidial dan pengayaan. Tindak lanjut merupakan pengambilan tindakan untuk langkah-langkah penilaian selanjutnya. Tindak lanjut penilaian untuk pembelajaran remedial meliputi aspek program remidial untuk siswa yang nilainya di bawah KKM, pemberian bimbingan kepada siswa yang mengalami kesulitan, pembelajaran ulang, pemanfaatan Tutor sebaya. Tindak lanjut pengayaan, meliputi aspek program pengayaan diberikan kepada siswa yang nilainya di atas $\mathrm{KKM}$, pengayaan kelompok untuk memecahkan, dan pemberian tugas untuk belajar mandiri.

Nilai komponen sistem dengan capaian tertinggi yaitu komponen guru dengan perolehan nilai 87,56. Artinya 87,56\% menyatakan bahwa guru sangat penting, hanya 12,44\% kurang penting. Indikator guru yang dianggap penting meliputi kompetensi, pengenalan masalah, kemampuan memamfaatkan TIK dan kelengkapan data penilaian autentik kurikulum 2013. Guru merupakan komponen pendukung utama karena sebagai subjek, objek dan pelaksanaan penilaian autentik kurikulum 2013. Nilai terendah dalam komponen sistem adalah sarana dan prasarana dengan perolehan nilai 85,31. Artinya $83,31 \%$ menyatakan bahwa sarana dan prasarana sangat penting, hanya $16,69 \%$ kurang penting. Sarana dan prasarana yang dianggap penting dalam penilaian autentik yaitu ketersediaan buku petunjuk penilaian bagi pengawas, kepala madrasah, serta guru, instrumen, media dan alat TIK.

Nilai HOTS dengan capaian tertinggi yaitu HOTS dengan perolehan nilai 90,00. Artinya 90,00\% responden menyatakan bahwa HOTS sangat penting, hanya $10,00 \%$ kurang penting. Indikator 
HOTS yang dianggap penting meliputi aspek kemampuan guru dalam proses berpikir logika dan penalaran tingkat tinggi level 3, proses berpikir menganalisis (C4), proses berpikir mengevaluasi (C5), proses berpikir mengkreasi (C6), dan membuat kata kerja operasional C4, C5, dan C6. Nilai capaian terendah adalah LOTS dengan perolehan nilai 85,42 . Artinya $85,42 \%$ responden menyatakan bahwa soal LOTS sangat penting, hanya $14,58 \%$ kurang penting. Soal LOTS yang dianggap penting meliputi proses berpikir mengetahui dan memahami pengetahuan faktual, konsep, serta prosedural dan membuat kata kerja operasional level (1).

Berdasarkan temuan dari model faktual, analisis kebutuhan kinerja sistem, komponen sistem dan HOTS, maka digambarkan pengembangan model penilaian autentik kurikulum 2013 dengan pendekatan HOTS berbasis kebutuhan guru di MI se Kecamatan Gebog sebagaimana pada gambar 2.

Gambar 2. Model Pengembangan Penilaian Autentik Kurikulum 2013 dalam Pembelajaran Tematik Berbasis HOTS di MI se Kecamatan Gebog

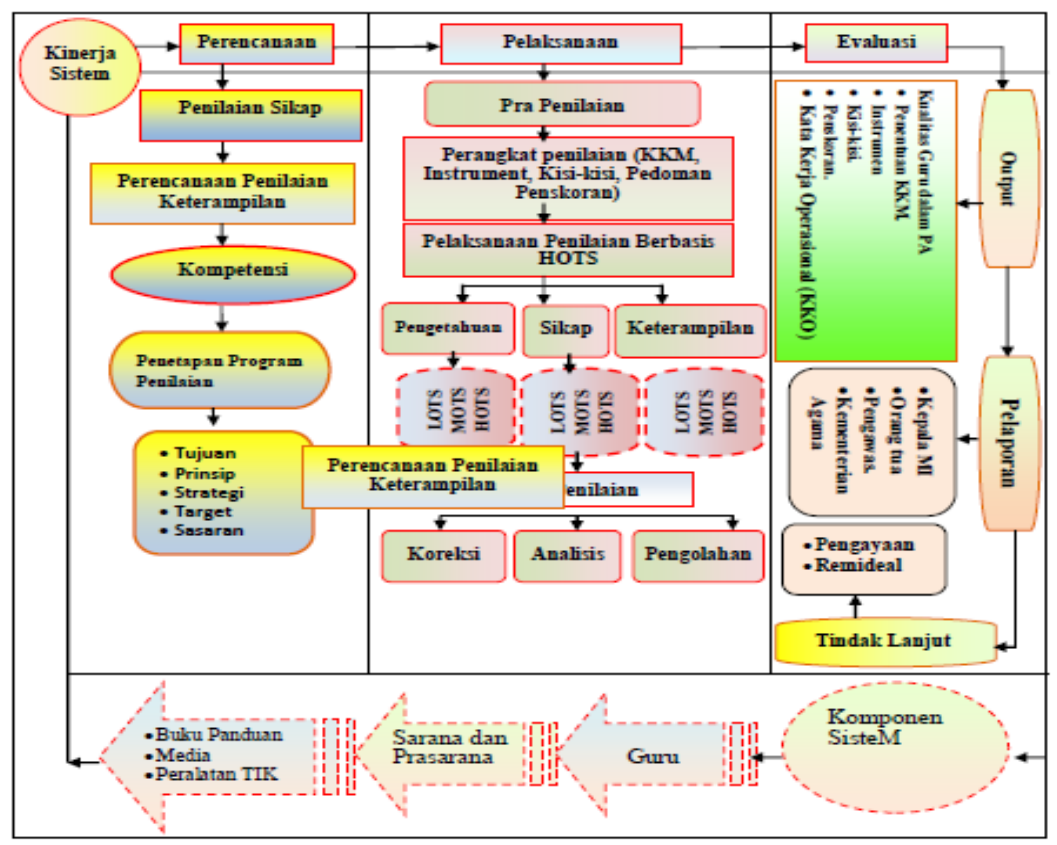

Elementary Vol. 7 No. 2 Juli-Desember 2019 
Berdasarkan gambar di atas, dideskripsikan pengembangan model penilaian autentik berbasis HOTS, sebagai berikut: Kinerja sistem meliputi perencanaan, pelaksanaan, evaluasi, output pelaporan dan tinadklanjut. Komponen sistem meliputi: guru, sarana dan prasarana, buku panduan, media, dan peralatan TIK. Kinerja sistem penilaian autentik meliputi: meliputi perencanaan, pelaksanaan, evaluasi, output pelaporan dan tinadklanjut, dijelaskan sebagai berikut.

Pertama, perencanaan. Perencanaan penilaian autentik kurikulum 2013 berbasis HOTS meliputi: perencanaan program penilaian pengetahaun (kognitif), afektif dan psikomotorik.

Perencanaan penilaian pengetahuan meliputi: (1) perencanaan tujuan penilaian untuk penguasaan pengetahuan (KD 3, KI-3, KI-4); (2) perencanan bentuk penilaian (ulangan, pengamatan, penugasan); (3) perencanaan teknik penilaian untuk mengukur penguasaan kompetensi pengetahuan (tes tertulis, lisan, dan penugasan). (4) perencanaan instrumen penilaian pengetahuan meliputi: kisi-kisi soal (materi/KD, butir soal, jumlah soal, dan sebaran pengetahuan faktual, prosedural, prosedural), kaidah soal, rubrik/pedoman penskoran. (5) perencanaan KKO meliputi C4: analisis, C5: evaluasi/ sintesis, C6; mencipta).

Perencanaan penilaian sikap meliputi: (1) perencanaan KD dan KI-1, KI-2; (2) perencanaan indikator sikap; (3) perencanaan teknik penilaian sikap; (4) perencanaan instrumen penilaian sikap (observasi dan penilaian diri); (5) perencanaan indikator pencapaian kompetensi (KD dan KI-1 dan KI-2) dan analisis kompetensi dan bahan ajar; (6) perencanaan Kata Kerja Operasional (KKO) melaiputi: menghargai (A3), pengorganisasikan (A4), karakterisasi menurut nilai (A5).

Penilaian keterampilan/ psikomotorik, meliputi perencanaan penilaian praktik, produk dan projek. Perencanaan praktik meliputi (1) merencanakan langkah-langkah (menentukan KD dan KI-4, indikator, kriteria/rubrik penilaian, menyusun tugas sesuai rubrik, mengujicobakan tugas, dan menyusun kriteria/batas kelulusan; 
(2) penyusunan kisi-kisi, (3) instrumen (kriteria tugas, lembar pengamatan, kriteria rubrik).

Perencanaan produk, meliputi (1) merencana-kan langkahlangkah penilaian produk (menentukan KD dan KI-4, menyusun indikator, tugas produk individu/ kelompok, teknik penilaian, instrumen dan rubrik penilaian, menyusun kriteria/batas penilaian), kisi-kisi, instrumen kriteria tugas, kriteria lembar penilaian produk, kriteria rubrik. Perencanaan projek, meliputi (1) merencana-kan langkah-langkah (menyusun kompetensi, penilaian projek, indikator, teknik, dan rubrik penilaian), kisi-kisi, instrumen dan pedoman penskoran/rubrik.

Kedua, pelaksanaan. Pelaksanaan penilaian autentik kurikulum 2013 dalam pembelajaran tematik berbasis HOTS dibagi menjadi tiga tahap yaitu pra penilaian, pelaksanaan, pasca penilaian. Tahap pra penialaian kegiatannya yaitu mempersiapkan perangkat penilaian (daftar hadir siswa, agenda mengajar, soal ulangan HOTS, daftar nilai, analisis ulangan harian, jurnal, program perbaikan dan pengayaan, KKM). Tahap penilaian berbasis HOTS meliputi penilaian sikap, pengetahuan dan keterampilan.

Penilaian sikap merupakan kegiatan untuk mengetahui kecenderungan perilaku spiritual dan sosial peserta didik dalam kehidupan seharihari, baik di dalam maupun di luar kelas sebagai hasil pendidikan. Penilaian sikap ditujukan untuk mengetahui capaian/perkembangan sikap peserta didik dan memfasilitasi tumbuhnya perilaku peserta didik sesuai butirbutir nilai sikap dari KI1 dan KI2. Kegiatan guru dalam melaksanakan penilaian sikap meliputi: (1) mempersiapkan perangkat penilaian sikap yang terdiri dari lembar observasi, wawancara, catatan anekdot, catatan kejadian, dan jurnal harian; (2) menentukan dimensi belajar siswa, meliputi (a) sikap dan persepsi (membantu siswa mengembangkan sikap dan persepsi positif tentang iklim belajar, dan tugas-tugsa belajar di kelas; (b) Mengintegrasikan pengetahuan (membantu siswa mendapatkan pengetahuan integratif dan proseduran; (c) memperluas dan menyaring pengetahuan luas (membantu siswa 
dalam penalaran kompleks); (d) menggunakan pengetahuan secara bermakna (membantu siswa mengembangkan proses penalaran kompleks; (e) Habits of minds (perilaku berpikir) yaitu membantu siswa berpikir positif mulai dari berpikir kritis, kreatif, pengaturan diri dalam berpikir. (3) aspek penilaian meliputi sikap spiritual, sosial, dan penguatan karakter. Sikap spiritual yang dinilai yaitu KI-1 (menghargai dan menghayati ajaran agama yang dianutnya); Sikap sosial yang dinilai KI-2 (menghargai dan menghayati perilaku jujur, disiplin, tanggung jawab, peduli (toleransi, gotong royong), santun, percaya diri. Penguatan Pendidikan Karakter (PPK) yang meliputi: religiositas, nasionalisme, integritas, kemandirian, dan gotong royong; (4) teknik penilaian meliputi observasi, wawan-cara, catatan anekdot (anecdotal record), catatan kejadian tertentu (incidental record) sebagai unsur penilaian utama; (5) penilaian hasil observasi guru terhadap sikap siswa yang menonjol (positif maupun negatif) saat pembelajaran dicatat dalam jurnal harian berorientasi pada HOTS; (6) penilaian diri dan penilaian antar teman, dan (7) merumuskan deskripsi penilaian sikap dengan memberikan predikat sangat baik, baik, dan cukup.

Penilaian pengetahuan berbasis HOTS, langkah-langkahnya meliputi: (1) mempersiapkan perangkat penilaian pengetahuan, meliputi format penilaian ulangan harian, nilai tugas, kisi-kisi soal, soal, penskoran/rubrik penilaian; (2) menentukan dimensi pengukuran penilaian pengetahuan (faktual, konseptual, prosedural dan metakognitif dalam berbagai tingkatan proses berpikir); (3) menentukan teknik penilaian (tes tertulis, lisan, dan penugasan) didasari pemikiran HOTS; (4) membuat langkah-langkah penilaian HOTS meliputi (1) penentuan KD, KI-3, KI-4); (2) menganalisis KD yang akan dibuat soal HOTS; (3) merumuskan KKO HOTS (analisis (analyzing-C4), evaluasi (evaluating-C5), dan kreasi (creating-C6); (4) menyusun kisi-kisi; (5) membuat soal-soal HOTS meliputi soal pilihan ganda kompleks, isian singkat, esay pada level 3 (analisis C4, evaluasi C5, dan kreasi C6); (6) Membuat kartu soal; (7) membuat Kunci jawaban, (8) membuat penskoran/rubrik penilaian; (9) koreksi; 
(10) pengolahan nilai HPH, HPTS, HPAS; (11) penentuan KKM; (12) deskripsi penilaian pengetahuan.

Penilaian keterampilan berbasis HOTS adalah penilaian yang dilakukan untuk mengukur kemampuan peserta didik dalam menerapkan pengetahuan dalam melakukan tugas tertentu di berbagai macam konteks sesuai dengan indikator pencapaian kompetensi. Penilaian keterampilan meliputi: praktik, produk, dan proyek.

Penilaian Praktik, adalah penilaian yang menuntut respon berupa keterampilan melakukan suatu aktivitas sesuai dengan tuntutan kompetensi. Penilaian praktik adalah kualitas proses mengerjakan/melakukan suatu tugas. Penilaian praktik bertujuan untuk mengukur capaian pembelajaran yang berupa keterampilan proses. Langkah-langkah penilaian praktik yaitu: (1) Mempersiapkan perangkat penilaian berupa pengamatan penilaian proses; (2) menentukan KD dan KI-4; (3) Menentukan indikator; (4) Membuat kisi-kisi; (5) Membuat tugas praktik; (6) Mengujicobakan tugas praktik; (7) Membuat kriteria/rubrik penilaian aktivitas kinerja praktik (TK= transfer knowledge, $\mathrm{CC}=$ critical thinking dan creativity, PS= problem solving); (8) Mengolah hasil nilai tugas; (9) Membuat deskripsi penilaian praktik.

Penilaian produk adalah penilaian terhadap keterampilan peserta didik dalam mengaplikasikan pengetahuan yang dimiliki ke dalam wujud produk dalam waktu tertentu sesuai dengan kriteria yang telah ditetapkan baik dari segi proses maupun hasil akhir. Langkah-langkah penilaian produk yaitu: (1) Mempersiapkan perangkat penilaian produk: (2) Menyiapkan bahan dan alat: (3) Menentukan KD, materi dan indikator; (4) Membuat kriteria/rubrik penilaian aktivitas kinerja praktik ( $\mathrm{TK}=$ transfer knowledge, $\mathrm{CC}=$ critical thinking dan creativity, PS= problem solving); (5) Membuat rerata; (6) Membuat deskripsi penilaian praktik.

Penilaian proyek adalah suatu kegiatan untuk mengetahui kemampuan siswa dalam mengaplikasikan pengetahuannya melalui penyelesaian suatu instrumen projek dalam periode/waktu tertentu. Penilaian projek dapat dilakukan untuk mengukur satu atau 
beberapa KD dalam satu atau beberapa mata pelajaran. Langkahlangkah penilaian proyek yaitu: (1) Mempersiapkan perangkat penilaian proyek; (2) Menentukan KD; (3) Menentukan indikator; (4) Membuat Kisi-kisi; (5) Membuat soal proyek; (6) Membuat kriteria/ rubrik penilaian; (7) Mengoreksi hasil pelaporan proyek.

Ketiga, evaluasi. Evaluasi merupakan kegiatan untuk menelaah/ menilai keberhasilan dalam melaksanakan proses dan hasil penilaian autententik kurikulum 2013 dalam pembelajaran tematik berbasis HOTS. Evaluasi dilaksanakan secara komprehensif. Sasaran evaluasi ditujukan kepada semua komponen dari setiap tahapan kegiatan mulai dari kegiatan perencanaan dan pelaksanaan serta output dari perangkat penilaian, instrumen penilaian (kisi-kisi, soal, rubrik penilaian) dan KKM.

Keempat, pelaporan. Pelaporan kegiatan penilaian autentik kurikulum 2013 adalah salah satu bentuk akuntabilitas/pertanggun jawaban guru dalam KBM. Pelaporan penilaian sikap dalam bentuk predikat dan deskripsi. Pelaporan penilaian pengetahuan dan keterampilan dalam bentuk dalam bentuk angka dengan skala 0-100. Pelaporan kepada pihak-pihak yang terkait yaitu: kepala MI, orang tua, pengawas dan Kementerian Agama Kabupaten Kudus.

Kelima, tindak lanjut. Tindak lanjut adalah melakukan tindakan sebagai refleksi atas keberhasilan atau tidak keberhasilan dalam penilaian autentik berbasis HOTS. Tindak lanjut diwujudkan dalam bentuk remedial dan pengayaan. Remedial diberikan kepada siswa yang nilainya di bawah KKM, sedangkan yang nilainya di atas KKM diberikan pengayaan.

Komponen sistem penilaian autentik kurikulum 2013 berbasis HOTS meliputi: guru dan sarana prasarana, dijelaskan sebagai berikut: pertama, komponen guru. Guru adalah komponen utama dalam penilaian autentik kurikulum 2013. Guru dituntut mampu melaksanakan penilaian autentik kurikulum berbasis HOTS. Oleh karena itu, guru harus memiliki kompetensi dan kualifikasi. Kompetensi yang harus dimiliki guru, yaitu (1) mampu membuat perangkat penilaian sikap, pengetahuan dan keterampilan; 
membuat KKM; (3) pemetaan KD, KI; (4) membuat KKO; (5) membuat kisi-kisi; (6) soal; (7) rubrik dan peskoran penilaian; (8) mengolah hasil nilai dengan memanfaatkan program aplikasi TIK; (9) mendeskripsikan; (10) membuat laporan penilaian. Kualifikasi guru dalam penilaian autentik meliputi: (1) tingkat pendidikan guru (D2, D3, S1, S2); (2) memiliki sertifikat pelatihan dalam penilaian autentik berbasis HOTS; (3) pengalaman/track record guru dalam melaksanakan penilaian autentik berbasis HOTS.

Kedua, komponen sarana dan prasarana. Sarana dan prasarana yaitu bahan/alat yang digunakan dalam penilaian autentik kurikulum 2013 berbasis HOTS meliputi: (1) buku petunjuk/panduan penilaian autentik; (2) media; (3) peralatan TIK yang digunakan untuk pengolahan penilaian berbasis HOTS

\section{Simpulan}

Berdasarkan hasil penelitian yang telah diuraikan sebelumnya, maka dapat dikemukakan simpulan sebagai berikut: (1) Kondisi faktual penilaian autentik kurikulum 2013 yang selama ini dilaksanakan oleh guru MI di Kecamatan Gebog dalam kategori kurang baik; (2) Desain pengembangan model penilaian autentik kurikulum 2013 dengan pendekatan HOTS sangat penting dan dibutuhkan sehingga layak digunakan untuk meningkatkan kemampuan penilaian guru MI di Kecamatan Gebog Kabupaten Kudus. Pengembangan model diperoleh fitur kinerja sistem meliputi: perencanaan, pelaksanaan, evaluasi, pelaporan dan tindak lanjut. Komponen sistem penilaian meliputi: guru, sarana dan prasarana berupa buku panduan dan media serta peralatan TIK.

Hasil pengembangan berupa Buku Panduan Penilaian Autentik dalam pembelajaran Tematik berbasis HOTS telah ditelaah dalam Focus Group Discussion (FGD), dan dinilai layak oleh Pakar dan Praktisi Pendidikan melalui uji coba terbatas, ujia coba diperluas dan uji kelayakan.

Saran disampaikan kepada kementerian Agama Kabupaten Kudus, kepala madrasah, dan guru hendaknya meningkatkan kinerjanya dalam penilaian autentik kurikulum 2013 mulai dari 
296| Mahfud Nahrowi

penentuan KKM, instrumen, kisi-kisi, penskoran, kata-kata Operasional (KKO), pendalaman penilaian pada soal HOTS dan pengolahan nilai. 


\section{DAFTAR PUSTAKA}

Barnett, J. E. \& Francis, A. L, “Using Higher Order Thinking Question to Foster Critical Thinking", Journal of Experimental Educational Psychology, Vol. 32, No. 2 ,2016

Basuki, Ismet. Asesmen Pembelajaran, Bandung: Remaja Rosdakarya, 2014.

Brookhart, How to Assess Higher-Order Thingking Skills in Your Classroom. Virginia USA: ASCD Alexandria, VA, 2010.

Dinni, Husna Nur, "HOTS (Higher Order Thinking Skills) dan Kaitannya dengan Kemampuan Literasi Matematika", Prisma Unnes, Vol. 1, No. 12018

Enggarwati, Nur Sasi, “Kesulitan Guru SD Negeri Glagah dalam Mengimplementasikan Penilaian Autentik Pada Kurikulum 2013", Jurnal Pendidikan Guru Sekolah Dasar UPY, Vol. 12, No. 4, 2015

Gultom, Syawal. Materi Pelatihan Guru Implementasi Kurikulum 2013 Tahun Ajaran 2014/2015. Jakarta: Pusat Pengembangan Profesi Pendidik Badan Pengembangan Sumber Daya Manusia Pendidikan dan Kebudayaan dan Penjaminan Mutu Pendidikan Kementerian Pendidikan dan Kebudayaan, 2014.

Hanif, Ma'mun, "Model Supervisi Klinis dengan Pendekatan Peer Coaching Grow Me dalam Penilaian Autentik pada Guru MTs Negeri di Kabupaten Brebes", Fakultas Ekonomi Universitas Tidar, Vol.1, No.1, 2017

Kementerian Agama Kabupaten Kudus, Daftar Penilaian hasil Belajar Kurikulum 2013 Tahun Pelajaran 2018-2019.

King, F., Goodson, L., \& Rohani, F., "Higher Order Thinking Skills: Definitions, strategies, assessment", Center for Advancement of Learning and Assessment. Tallahassee, FL: Florida State University, Vol. 1, No. 3 , 2011

Kunandar, Penilaian Autentik (Penilaian Hasil Belajar Peserta Didik Berdasarkan Kurikulum 2013) Suatu Pendekatan Praktis. Jakarta: Raja Grafindo Persada, 2015.

Elementary Vol. 7 No. 2 Juli-Desember 2019 
Mainali, "Higher Order Thinking in Education", A Multidisciplinary, Vol. 2, No. 1, 2012

Masrukhin, "Pengembangan Instrumen Penilaian Otentik Mata Pelajaran Pendidikan Agama Islam untuk Meningkatkan Kemampuan Evaluasi dalam Pembelajaran", Seminar Nasional Evaluasi Pendidikan, Semarang 22 November 2014, Universitas Negeri Semarang: 724

Moon T.R. C.M. Brighton \& C.M. Callahan, “Development of Autentic Assessments for The Middle School Classroom", Journal of Secondary Gifted Education Vol. 2, No. 3, 2016

Mueller, J., "Authentic Assessment in The Classroom and The Library Media Center", Library Media Connection, Vol. 23, No. 7, 2005 Rahmanto, Arju. Efektifitas Materi Peer Coaching pada Diklat Implementasi Kurikulum 2013 bagi Pengawas Sekolah dalam Mensupervisi Kepala Sekolah Mengimplementasikan Kurikulum 2013 di Sekolah. Semarang: LPMP Jawa Tengah. 2013.

Sugiyanto, "Penggunaan Penilaian Autentik dalam Pembelajaran Biologi dengan Inkuiri Terbimbing Dan Pengaruhnya Terhadap Hasil Belajar Peserta Didik", Biol.Educ, Vol. 4, 2015 Supriano, Buku Penilaian Berorientasi Higher Order Thinking Skill (HOTS), Jakarta: Direktorat Jendral Guru dan Tenaga Kependidikan, 2018.

Tegeh, I Made \& Kirna, I Made, "Pengembangan Bahan Ajar Metode Penelitian Pendidikan dengan ADDIE Model", Jurnal IKA, Vol 11, No. 1, 2013

Todorov, Karen R., "Authentic Assessment of social studies", Michigan Department of Education Curriculum Development Program Unit. Vol. 5, No. 3, 2009 